\title{
Reflections on the Need of Administrative and Tort Legislation Separate Codification in Cis States
}

Vladilen Gaykovich Tataryan

FGBOU VPO "Russian State University of Tourism and Service", Eurasian Academy of Administrative sciences

Ivan Nikolaevich Mishurov

FGBOU VPO "Russian State University of Tourism and Service"

Sergey Aleksandrovich Kokotov

FGBOU VPO "Russian State University of Tourism and Service"

Elena Evgenievna Tataryan

FGBOU VPO "Russian State University of Tourism and Service", 141221, Moscow Region Pushkin district, Cherkizovo Street, Building 99

\section{Doi:10.5901/mjss.2015.v6n5s2p454}

The authors carried out a general comparative legal analysis of the administrative and tort legislation of the CIS countries in the last twenty years. They expressed their views on the current state of the above-mentioned codified acts and made a number of proposals aimed at further improvements by separate codification.

Keywords: administrative and tort law and legislation, Codes of the CIS countries, substantive and procedural rules.

\section{Introduction}

Today, after more than twenty years after the collapse of the USSR, it is possible to bring some results of cardinal improvement of national administrative and tort legislation in the CIS states. Our study of the legislative activities of CIS parliaments, starting from the middle of the 90s of the last century, allows us to assert that in Uzbekistan, Kyrgyzstan, Azerbaijan, Kazakhstan and Russia, the basis for the creation of new codified acts on administrative liability is the principle of joint codification of substantive and procedural rules of national administrative and tort law. In the above countries, to the middle of the first decade of the new century, the legislative work on the implementation of the second codification of administrative and tort law as a whole has already been completed.

At present, the further improvement of adopted Codes is carried out. Sometimes it happens with the "help" of dozens of new laws introducing changes and additions in the substantive, procedural and executive parts of the Code. For instance, in the Code of Administrative Offences of the Russian Federation, before 13 years since its adoption, legislators of the six convocations of the State Duma of the Federal Assembly of the Russian Federation made a significant number of changes and additions in all five sections of the Administrative Code of the Russian Federation, while taking about 400 federal laws. At the same time, we note that the Russian legislators, unfortunately, still do not go on the course of the Belarus and Kazakhstan legislators, who have been developing a significant volume of laws for several years, but do not "deminish" them by 2-3 lines like their Russian counterparts often do. There are no more than 35 laws per year, unless, of course, there is no urgent need to immediately make the appropriate changes and additions to the national legislation of these countries.

In fairness, it should be noted that at present, the country has a legislative work on the separate development of new codes of Russia. Administration and Procedure Codes of the Russian Federation are their holding titles. We hope that in 2015, in Russia finally, two separate codified acts will be exercised. By the way, more than 20 years, we advocate for them to be named: Administration and Tort, Procedure and Tort Codes of the Russian Federation But in more detail, this question will be discussed in our next work.

Further, it should be explained that in other countries of the Commonwealth (Armenia, Moldova, Tajikistan, 
Ukraine), by mid-teens of the $21^{\text {st }}$ century, this legislative work has not yet been completed. However curious to relate, almost to the end of the first decade of this century, some operating first codification Codes (Tajikistan and Moldova) was attended by legal provisions that used Soviet socialist law terminology (for instance, the Soviet order, socialist legality, socialist ownership, the Ministry of Defense of the UUSR, the Ministry of Internal Affairs of the USSR, and so on.)

By the way, the first codification of administrative responsibility norms was also marked by a number of features, which subsequently had a significant impact on the systematization process of the Soviet and republican administrative and tort legislation. Firstly, it should be noted that the Soviet legislation and, above all, the foundations of the USSR and the Union Republics of Administrative Offences were the Code of the Soviet Republics' basis on administrative violations of an administrative and tort rules (October 1980), which resulted their uniformity both in structure and content. Unfortunately, few people remember this (Tataryan, 2005). Secondly, along with the above codes, the acts of local Congress of People's Deputies and their executive committees were standard legal sources of administrative responsibility that ultimately did not allow the Codes to become the only legal act of the Soviet Republic, governing the administrative responsibility. Third, so-called "mixed" codification was carried out for substantive, competency and procedural norms of the Administrative Offences.

However, we emphasize again that the value of the first Administrative Code of the Union Republics is difficult to overestimate (Duabekov, 1995). As noted above, the first codification of administrative responsibility was carried out in two stages. In the first stage, in October 1980, for the first time in the USSR, the Fundamentals of Legislation of the USSR and the Union Republics of Administrative Offences were established, and later in 1984-1985, that is in the second stage, the first time in the Soviet Union, on the basis of the aforementioned Fundamentals, the Administrative Codes the Soviet Republics were adopted. In the mid-80s of the last century, the adoption of the first Administrative Codes of the Soviet Republics meant not only the creation of single systematic legislation on administrative responsibility in each Republic, replacing dozens, and sometimes hundreds of separate acts at various levels, but also it significantly meant the finalization of a new independent branch of law, that is the administrative and tort law (Emelyanov, 2004). For the first time, normative regulation was ordered to combat one of the most common types of crimes, these are administrative offenses (misdemeanors), the grounds and administrative sanctions were defined, the subject system of administrative jurisdiction was fixed, the administrative and jurisdictional process were regulated, as well as the order of execution of the decisions made in the case.

\section{New Administrative and Tort Codified Acts in CIS}

With regard to the conceptual new administrative and tort codified acts of the CIS countries, we believe that they also have a number of features that are different from the national codification of the Administrative Code of the Soviet period. Here are some of them: i) basic fundamental legal provisions included in the new codified acts on administrative responsibility of the CIS are now consistent with the new Constitution of the CIS countries and aligned with the universally recognized norms of international law; ii) in the development of the main institutions of the administrative and tort law, the CIS legislators abandoned outdated norms of the Soviet socialist law; iii) Some novelties included in the total competency and procedural part of the new codes "saw the light" thanks to modern advances in the theory of national tort CIS law (criminal and civil); iv) At the same time, the developers of these codified acts found it possible to save in the new Codes, norms positively proven in the enforcement of administrative jurisdictions; v) Structuring the content of the sections of the Special part of the new codes by the CIS parliamentarians, the priority of the protection of the individual's constitutional rights and freedoms, and then of the society and the state was considered as the overriding priority.

The development and adoption of the new codified acts on administrative liability by the CIS countries were due to profound changes in the life of post-Soviet society in these countries, which is reflected in the new Constitution adopted in all the CIS countries by the mid-90s of the last century. For the first time in its history, the new Constitutions of the Commonwealth countries proclaimed priority of the man and citizen's rights and freedoms as the highest social value. The initial reformation stage of the national legislation in the Commonwealth countries was characterized by a considerable amount of the codification work. For instance, in Belarus, this work was started in accordance with the Presidium Decree No. 3777-XII of the Supreme Soviet of the Republic of Belarus dated May 30, 1995 «On the organization of temporary creative team on the drafting of the Civil, Civil Procedure, Criminal, Criminal Procedure, Administrative and Procedure Codes and the Code of Administrative Offences" ("Resolution of the Presidium of the Supreme Soviet of the Republic of Belarus"), 1995, Section 317; "Reform Legislative Support Program", 2000; "Presidential Decree No. 949 of the Republic of Kazakhstan dated September 20, 2002", 2002; "Resolution No. 1430 of the Government of the Republic of Kazakhstan dated December 29, 2002", 2004).

In Russia, unfortunately, the question of drafting of two separate codified administrative and tort acts, where the 
substantive and procedural rules have been separately codified, was removed at the initial project stage of the new Code of Administrative Offences ("Resolution No. 830 of the Government of the Republic of Kazakhstan dated August 21, 2003", 2003; "Resolution No.598 of the Government of the Republic of Kazakhstan dated May 30, 2002", 2002, Section 172; Ignatenko, 2003; Bachrach, Manohin and Pavlovski, 1988; Dodin, 2004).

In contrast, in some CIS countries at the end of the 90s at the national level, it was decided to start the development of a new national administrative legislation. Thus, in particular, in Turkmenistan, a program of legislative support of reform and transformation has been developed and adopted by Saparmurat Turkmenbashi, the first President of Turkmenistan. This program included a "reasoned scientific ideas and practical recommendations to the President on issues of state-building, rule of law and legislation, economic development and social development, further strengthening the high authority, which independent neutral Turkmenistan uses in the international political arena. "In the second section of the aforementioned program, the $2^{\text {nd }}$ part was incorporated named "Legal Basis of the Proceedings. Codification of the penitentiary legislation. Developing a new administrative law". It fixed a historic decision to create a conceptually new national administrative and tort legislation of independent Turkmenistan, "which will be built on a fundamentally new legal scheme, involving the preparation of two separate and related laws -the Code of Administrative Responsibility and Code of Administrative Procedure." Next, the program of the reform and transformation legislative support of Turkmenistan noted that "in contrast to the existing Code of Administrative Offences, which includes both the substantive and procedure law, a new system of administrative law would allow the country to more specific and fully consolidate the structure of administrative violations, to determine sanctions proportionate to illegal actions, as well as to provide a separate law with clear legal and administrative procedures and execution of decisions of the competent state bodies and officials".

However, in fairness, we should note that the above program's conceptually new administrative tort codified acts planned in Turkmenistan have not been taken. The united conceptually new codified act -the Code of Administrative Offences of the Republic of Turkmenistan -was passed only August 29, 2013 and entered into force on January 1, 2014. Since the same date, the Code of Administrative Offences, which was approved by the Law of the Turkmen SSR dated December 17, 1984, will become void.

By the way, in 2009, in the Republic of Kazakhstan, it was decided to prepare two drafts of the codified acts with the same name. However, the work of the Kazakh legislators also was not finished. Moreover, a new edition of the Administrative Code of the Republic of Kazakhstan has been prepared, which has already caused considerable criticisms by scientists because of the significant novelties that differ a lot from the basic provisions of the Code, not only of the CIS countries but also the countries of the Customs Union, namely Russia and Belarus. And if it is adopted in a prepared version, that could lead to very significant issues.

Formation of the rule-of-law state, the new socio-economic structure that has been established in the Constitutions of the CIS countries, led to the need to find ways to effectively protect the new "market" public relations began to take shape in the second half of the 90s of the last century by the administrative and legal means.

Our study allows us to reduce the basic preconditions of the necessary second codification of administrative and tort law to the following. Firstly, there is no doubt that the administrative and jurisdictional protection shall be adequate to the existing new realities of modern life.

On December 18, 2013, the Law of Turkmenistan "On the application of the Code on Administrative Offences of Turkmenistan" was adopted, where first of all, the law enforcers were explained the procedure of its application. In particular, in Section 1, the legislator pointed out that according to the Turkmen SSR Code of Administrative Offences, approved by the Law of the Turkmen SSR dated December 17, 1984, if the decision on the administrative penalty for actions, which are not recognized as administrative offenses under the Code of Administrative Offences of Turkmenistan, approved by the Law of Turkmenistan dated August 29, 2013, is not performed up to January 1, 2014, the person, on whom an administrative penalty, which has been imposed under this Regulation, shall be exempted from this administrative penalty, and the proceedings of an administrative offense shall not be considered in the same period, it shall be discontinued.

Section 2 of the Law established that not fulfilled administrative penalties imposed on persons under the Code of Administrative Offences of the Turkmen SSR, approved by the Law of the Turkmen Soviet Socialist Republic dated December 17, 1984 are in line with the Code of Administrative Offences of Turkmenistan, approved by the Law of Turkmenistan dated August 29, 2013, only in those cases where the imposition of the administrative penalty is more severe than that provided by the relevant sections of the latter Code.

Separately, the third section of the Law states that Section 321 of the Administrative Code of Turkmenistan approved the Law of Turkmenistan on August 29, 2013, shall come into force only from January 1, 2016. Note that we are talking about the section posted in the Special Part of the new Administrative Code, which provides the liability for 
"violation of the order of reception of payment cards", namely the refusal to accept payment cards by bank employees of enterprises of trade, catering and other services, regardless of ownership, as well as individuals engaged in entrepreneurial activity. For more details, we will try to analyze the content of this section in the following parts of our publication (Tataryan, Tataryan and Mishurov, 2014).

In conclusion, thanks to the development and adoption of the above-mentioned Code of Turkmenistan, albeit with significant delay, but it entered the group of post-Soviet countries, which have a modern administrative and tort legislation. If it is effective, it remains to be seen.

\section{Background of the Codes of Administrative Offences in the CIS}

In using of the first Administrative Codes of the Soviet Republics (of the mid 80s of the last century), many of their rules are outdated and irrevocably "passed away". Second, nearly 20-year-old administrative and jurisdictional experience of the "old" Administrative Code of the Soviet Republics revealed the existing conflicts and gaps of the above legislation. We recall here that during the action of the Administrative Code of the Russian Soviet Federated Socialist Republic (RSFSR), more than two hundred of its sections have been somehow changed. However, only in the second half of the 90s of the last century, it was introduced more than 120 new formulations of administrative offenses, many of which are clearly discordant with the "old" rules of the Soviet socialist law. However, attempts to introduce numerous local changes and amendments to the Administrative Code of the RSFSR (sample of 1984) by the end of the 90s of the last century finally exhausted themselves and, moreover, compromised. This legal situation had (and in some places, it still has) the place to be in a number of the CIS countries (Tataryan, 2008a; Tataryan, 2008b; Tataryan, 2009). Beginning the construction of a democratic state in the CIS countries, the modern society needed doctrinally and conceptually new codified act regulating the issues of the administrative responsibility. Third, the legal and regulatory framework based on the law of the Soviet Union Centre (Legislation Fundamentals of the Administrative Offences of the USSR and the Soviet Union Republics (1980), Decree of the Presidium of the Supreme Soviet of the USSR, the Decisions of the Government of the USSR and others), through which the struggle with administrative offenses came in clear and irrevocable conflict with the provisions of the new Constitution of the CIS countries ("Constitution of the Republic of Belarus", 2014; "Constitution of the Republic of Kazakhstan", 2014).

To the mid-90s, the Codes adopted in the mid-80s of the last century did not fit into a new constitutional space of the CIS. This observation applies both to the level of legal regulation in this area and real guarantees of the legitimate rights and freedoms of members of administrative and tort process, first of all, the delinquent and the victim. The issue of proper maintenance of the man and citizen's rights and freedoms in the field of law enforcement has become more urgent due to the Commonwealth of Independent States ratification of the Convention on Human Rights and Fundamental Freedoms (Protocol 1 to the Convention for the Protection of Human Rights and Fundamental Freedoms dated March 20, 1952, 1998; Protocol 4 dated September 16, 1963 to the Convention for the Protection of Human Rights and Fundamental Freedoms "On securing certain rights and freedoms other than those already included in the Convention and Protocol 1", 1998; Protocol 7 dated November 22, 1984 to the Convention for the Protection of Human Rights and Fundamental Freedoms, 2001, Section 163; Universal Declaration of the Rights of Man, 1991, Section 1865).

Fourthly, the administrative sanctions began to defend the norms of various branches of the new national law of the CIS countries (including customs, land, environmental, water, etc.), but their (the sanctions) efficiency dropped significantly, and they could not fully carry out their security functions. We also recall the CIS parliamentarians developing the conceptually new criminal codes of the countries, although abandoned compositions with administrative prejudice, decriminalized a number of socially dangerous acts, however, included a significant number of crimes in the Special Part of the Criminal Code, related to the corresponding formulations of administrative offenses (Criminal Code of the Republic of Kazakhstan, 2014, the Criminal Code of the Kyrgyz Republic, 2014; Criminal Code of the Republic of Moldova, 2014; Criminal Code of the Republic of Armenia, 2013; Criminal Code of the Republic of Uzbekistan, 2014; Criminal Code of the Republic of Tajikistan, 2014). We should also remind the reader, and that the development of the new criminal legislation of the CIS countries was not carried out "in a vacuum" (Maksimov, 2002). In the first half of the 90s of the last century, a tight integration of legal scholars, legal practitioners and members of parliament of the Commonwealth countries has played a significant role in the preparation of the new Criminal Code. As a result of this joint legislative work, the model criminal code for CIS countries was adopted (Model Criminal Code for the participants of the CIS, 1996; Kuznetsova, 2003). In fairness, it should be noted that in 1996, at the seventh plenary session of the Interparliamentary Assembly of the Commonwealth of Independent States, the Civil Code was adopted, which also was a recommendation for a legislative act of the Commonwealth of Independent States. This happened on February 17, 1996 (Civil Code: Part Three, 1996). A year earlier, on February 10, 1995, the Decision of the Council of Heads of the Commonwealth of 
Independent States have taken Customs Fundamentals of the Commonwealth of Independent States (Fundamentals of Customs Legislation of the Commonwealth of Independent States. Decision of the Council of the CIS Heads dated February 10, 1995, 1995).

A certain legislative work was carried out at the interregional level in the CIS countries. For example, on June 7, 1997, the Interparliamentary Committee of Belarus, Kazakhstan, the Kyrgyz Republic and the Russian Federation four countries approved designed Regulation on the model and other legislative acts of the Interparliamentary Committee (Basic documents regulating the activities of the Interparliamentary Committee, 1998). Therefore, in our opinion, the second codification of the national administrative and tort legislation of the CIS countries was intended not only to streamline the administrative and tort legal relations, but also significantly enhance intra-communication in the structure of the new national tort laws of the CIS and the Customs Union (Adushkin, 2004).

Finally, fifthly, the appropriate scientific basis was created for the second codification. In particular, the scientists of Russia, Belarus, Kazakhstan and other CIS countries tried not only to justify the concept of the national administrative and tort law and the process (Tikhomirov, Nozdrachyov, Hangeldyev et al., 1998; Tikhomirov, 1998; Salishcheva, 1995; Shergin, Tataryan and Omarov, 1998), but studied their basic institutions (Shergin, 1979; Shergin, (eds.), 1999), a new doctrine of administrative and tort process was developed (Maslennikov, 1990), the author's versions of the administrative and tort codes or their individual sections, paragraphs and chapters were suggested (Sevryugin, 1994; Tataryan, 1998; Tataryan, Seylhanov, 1995). These comments can be fully attributed to the development of the administrative and tort law of the other CIS countries, including Kazakhstan, Kyrgyzstan, Azerbaijan and Uzbekistan (Alimov, 2002; Grigoriev, 1997; Tataryan, Nazarbayev, 2000). The presence of these and those assumptions created favorable conditions for development of the new legislation on administrative responsibility in the CIS countries.

Keeping mostly previously existing structure of the Administrative Code of the first period of codification, the new codes of the CIS countries have incorporated a significant number of legal novelties. This primarily relates to bringing the legislation on administrative responsibility in accordance with the Constitution of the CIS and updated national legislation of these countries.

Secondly, the draft of the CIS codes were based on the requirements of international legal acts that introduced the priorities of protecting the rights and freedoms of man and citizen, the idea of a democratic constitutional state, a mixed economy and security, new relationships arose in society in the period of transition to a market economy.

Third, almost all conceptually new codes of the CIS countries for the first time envisaged the introduction of a new subject of administrative responsibility, such as legal entity. At the present time, as we noted above, only the Code of Administrative Responsibility of the Republic of Uzbekistan has not yet provided the administrative liability of legal entities.

Fourth, in the new codes of the CIS countries in more detail, in accordance with international legal standards, the administrative and tort process procedure has been developed (for example, novelties have been adopted governing the holding of any administrative investigation in the case, a specific procedure has been set for the application of measures of the administrative process, including the opportunity to appeal their application, a remedial order has been upgraded for execution of the decisions in the case, and others.)

Fifth, compared with the Administrative Code of the Soviet period, the new codes of the CIS countries (except for the adopted Procedural and Executive Code of the Republic of Belarus in 2006) have very significantly expanded the list of subjects of administrative jurisdiction authorized to consider cases on administrative offenses. In some codes, the list now reaches 40-60 subjects and tends to increase.

For example, in the Administrative Cod of December 20, 2014 in the 23rd section "Judges, agencies, officials, authorized to consider cases on administrative offenses", the total number of sections, which set out a list of significant administrative jurisdiction, reaches a number of 89 . However, during the same period (13 years!) 20 sections (please count: 20 executive power authorities) has been abolished from this list. And that's without taking into account the suppressed parts of these sections. This happens even though the fact that in the new codes, judges are entitled to consider a much larger number of administrative cases than before.

At the time, the total liberalization of the tort law hardly related to some of the principal provisions of the new codified acts. For example, some codes of the CIS countries essentially reproduced the previously existing in the Soviet Union, the system of the administrative penalties. Moreover, as a result of some legal novelties, a level of the Code administrative and legal repression was even increased.

\section{Conclusion}

A new national administrative and tort legislation of the CIS countries have been called to play an important role in 
ensuring the realization of the planned policy of social and economic reforms and an adequate level of maintenance of public order and public safety in the country. It was supposed to provide guarantees of man rights not on paper (as it was often the case in previous years), but in real life. No doubt, the legislators of all countries of the Commonwealth of Independent States sincerely sought to such a result, engaged in a radical reform of the legislation.

Thus, in solidarity with the opinion of JA Tuyakbay, the former Majilis Parliament Chairman of the Republic of Kazakhstan, who in the middle of the first decade of the new century, rightly noted that "growing array of legal system of the former USSR, fueled by its legal concepts, institutions and norms, the legislation of the former Soviet Republics and now of sovereign states united in the CIS carries both traces of the past and the new sprouts" (Tuyakbay, 2004a; Tuyakbay, 2004b). In our view, this judgment has not lost its relevance. This formula will address the combination issue of legal continuity and legal innovations in conducting large-scale political, economic and social reforms in the CIS countries. And because the legislative work in the CIS countries in this direction is actively continuing, we hope that in the near future in a legislative "baggage" of the CIS countries, the conceptually new codified acts will occur, in which, finally, following the example of the Republic of Belarus, and now with 2013 and the Republic of Tajikistan, the substantive and procedural administrative and tort rules will not only be "divided in their apartments" but also, and this is more important, will undergo further significant changes to ensure the protection of constitutional rights and freedoms of both citizens and legal entities involved in the administrative and tort process.

\section{Normative Sources and Bibliography}

Tataryan, V., Tataryan, E., \& Mishurov, I. (2014). Conceptually New Administrative Offence Code of Turkmenistan: General Analysis of its Structure and Some Author's Reflections. World Applied Sciences Journal, 32(1), 88-91.

Shergin, A., Tatarian, V., \& Omarov, I. (1998). Actual problems of administrative and tort law and legislation. Constitution of the Republic of Kazakhstan and problems of its realization in the current legislation: Collection of research papers, VSH National Security Committee, 84-91.

Shergin, A. (1979). Administrative jurisdiction. Moscow; Shergin, A. (Ed.). (1999). Basic institutions of administrative and tort law. Moscow: Institute of the Ministry of Interior Affairs of the RF.

Adushkin, Y. (2004). Reforming the institution of administrative liability under the laws of the Kyrgyz Republic. In Administrative and procedural law. Urgent problems. Moscow: UNITY-DANA, Laws and regulations.

Alimov, H. (2002). Improving the administrative legislation of the Republic of Uzbekistan in the conditions of transition to a market economy. Actual problems of legal reform in the states - members of the Commonwealth of Independent States: Collection of research papers. In 2 Vol. Vol. 1., 38-46.

Bakhrakh, D., Manohin, V., \& Pavlovsky, R. (1988). Administrative law and perestroika. Jurisprudence, 6, 49-52.

Tataryan, V., \& Nazarbayev, K. (2000). Administrative and tort law: urgent problems, and the author's view on the way of its radical improvement. Legislation and law enforcement in the Russian Federation and the Republic of Kazakhstan: Theory and Practice: Collection of research papers, Moscow, 5-35.

Tataryan, V. (1998). Author draft of "Administrative offences in the field of fire safety" section of the Administrative Code of the Republic of Kazakhstan. Almaty: Fire Safety Service Department of the Committee for Emergency Situations of the Republic of Kazakhstan.

Universal Declaration of Human Rights. (1991). Bulletin of the Congress of People's Deputies and the Supreme Soviet of the RSFSR, 52, Sec. 1865.

Civil Code Part Three: Advisory Law for the Commonwealth of the Independent States Adopted at the seventh plenary session of the Interparliamentary Assembly of the Commonwealth of Independent States. (1996, February 17). Newsletter, 10 (Supplement).

Grigoriev, V. (1997). Administrative and jurisdictional problems of Kazakhstan in the last decade of the twentieth century. Materials of scientific and theoretical conference in Kazakhstan on the threshold of the twenty-first century, Almaty, 4, 34-36.

Dodin, E. (2004). The place and role of administrative law in the regulation of social relations in Ukraine. In L. Popov \& M. Studenikin (Eds.), Administrative law and administrative process: actual problems (pp. 90-98). Moscow: Lawyer.

Duabekov, T. (1995). Problems of the law codification on administrative offenses (Substantive and procedural aspects). Problems of improving the administration of internal affairs bodies in the Republic of Kazakhstan in transition to a market economy: Collection of research papers, Karaganda, VSH Interior Ministry of the Republic of Kazakhstan, 3-11.

Emelyanov, S. (2004). Reforming the administrative responsibility of the Administrative Code of Ukraine. Actual problems of economic security: International scientific and practical conference dedicated to the $10^{\text {th }}$ anniversary of the financial police. Part 2, Astana, 151-156.

Ignatenko, V. (2003). Administrative and tort law-making: the concept and function. Administrative right at the turn of the century: Intercollegiate scientific papers, Ekaterinburg, Ural University Press, 196-209.

Constitution of the Republic of Belarus. (2014). Minsk: Amalhteia; Constitution of the Republic of Kazakhstan. (2014). Almaty: Lawyer.

Kuznetsova, N. (2003). Comparative analysis of the crime institute under the Criminal Code of the CIS and Baltic States. Bulletin of Moscow University, Series 11, Right, 3, 19-35.

Maslennikov, M. (1990). Administrative and jurisdictional process. Voronezh. 
Maximov, V. (2002). The new criminal legislation of the Republic of Kazakhstan. Russian investigator, 4, 41-48.

Salishcheva, N. (1995). About the new Code of Administrative Offences. Russian Justice, 12.

About the significance of this historic event and content of a model of the Criminal Code. Model Criminal Code for the CIS. (1996). Jurisprudence, 1, 92-150.

The main documents regulating the activities of the Interparliamentary Committee. (1998). St. Petersburg.

Basics of customs legislation - the Commonwealth of Independent State. Decision of the Council of the CIS Heads. (1995, February 10). Bulletin of international agreements, 9.

Resolution of the Government of the Republic of Kazakhstan No. 840 "On approval of the organization of legislative work in the authorized bodies of the Republic of Kazakhstan". (2003, August 21). Astana.

Resolution of the Government of the Republic of Kazakhstan No. 1430 "On the Program of pro-crime prevention and the fight against crime in the Republic of Kazakhstan for 2003-2004". (2002, December 29). As amended by Resolutions of the Government of the Republic of Kazakhstan No. 1216 dated 29/11/2003, No. 651 dated 15/06/2004, No. 861 dated 13/08//2004.

Resolution of the Government of the Republic of Kazakhstan No. 598 "On measures to improve rulemaking". (2002, May 30). As amended 898 dated September 4, 2003. SAPP RK, 16, Sec. 172.

Decree of the Presidium of the Supreme Soviet of the Republic of Belarus No. 3777-XII "On the organization of temporary creative team on the drafting of the Civil, Civil Procedure, Criminal, Criminal Procedure, Administrative Procedure Code and the Code of Administrative Offences". (1995, May 30). Bulletin of the Supreme Council of the Republic of Belarus, 22-23, Art. 317.

Program of reform and transformation legislative support by Saparmurat Turkmenbashi, the President of Turkmenistan. (2000). Ashgabat.

Protocol 1 to the Convention for the Protection of Human Rights and Fundamental Freedoms. (1952, March 20). Bulletin of international agreements, 1998, No. 7, No. 12.

Protocol 4 to the Convention for the Protection of Human Rights and Fundamental Freedoms. (1963, September 16). Securing certain rights and freedoms other than those already included in the Convention and the Protocol 1. Bulletin of international agreements, 1998, No. 7, No. 12.

Protocol 7 to the Convention for the Protection of Human Rights and Fundamental Freedoms. (1984, November 22). Bulletin of international agreements, 1998, No. 9, No. 12. Meeting of the legislation of the Russian Federation, 2001, 2, Sec. 163.

Sevryugin, V. (1994). Theoretical problems of administrative offense. (1994). Synopsis of a thesis, Moscow.

Tataryan, V. (2009). Administrative and tort legislation of the Republic of Kazakhstan: the formation, by-state and its further development after independence. Company during the financial crisis: the economy, politics, law: Proceedings of the International Scientific and Practical Conference (Eka-SCANIA, 2009), Part 1, Ekaterinburg, Ural Institute of Economics, Management and Law Press.

Tataryan, V. (2008a). Objective and subjective trends in the development and improvement of the administrative and tort legislation of the CIS countries: the case of the Administrative Code of the Republic of Azerbaijan. Actual problems and prospects of legal science and practice in the states - members of the Commonwealth of Independent States: Proceedings of the International scientific and practical remote Conference. Issue No. 4. In 2 Vol. Vol. II, Moscow, Academy of economic safety of the Ministry of the Interior Affairs of the RF.

Tataryan, V. (2008b, February). The conceptual basis of the author of the model Code of Administrative and tort for the Union State of Belarus and Russia. Bulletin of the Ural Institute of Economics, Management and Law, 1(2).

Tataryan, V. (2005). Formation of the Soviet administrative and tort legislation: the $25^{\text {th }}$ anniversary of the adoption, at the Fundamentals of Legislation on Administrative Offenses of the USSR and the Union Republics. History of State and Law, 4, 45-49.

Tataryan, V., \& Seylhanov, M. (1995). The draft of the new Code of the Republic of Kazakhstan on administrative offenses: the conclusion of the expert committee and author suggestions. Karaganda: Karaganda higher school of the Ministry of Interior of the Republic of Kazakhstan.

Tuyakbai, J. (2004a). The socio-political conditions and milestones reforming law in Kazakhstan. Russian investigator, 6, 43-47.

Tuyakbai, J. (2004b). On the negative factors of the reform of justice in Kazakhstan. Russian judge, 4, 45-47.

Criminal Code of the Kyrgyz Republic. (2014). Bishkek.

Criminal Code of the Republic of Armenia. (2013). Yerevan: Publishing House of the Ministry of Justice of the Republic of Armenia.

Criminal Code of the Republic of Kazakhstan. (2014). Almaty: Baspa Publishing house.

Criminal Code of the Republic of Moldova. (2014). Chisinau.

Criminal Code of the Republic of Tajikistan. (2014). Dushanbe Univ GUT "Konunov".

Criminal Code of the Republic of Uzbekistan. (2014). Tashkent: Adolat Publishing House.

Presidential Decree No. 949 "On the Concept of Legal Policy of the Republic of Kazakhstan". (2002, September 20). Astana.

Tikhomirov, Y., Nozdrachyov, A., \& Hangeldyev, B., et al. (1998). The concept of administrative and procedure law. In Concept of development of the Russian legislation. Moscow.

Tikhomirov, Y. (1998). On the concept of administrative law and procedure. State and Law, 1. 